\title{
Serum Calcitonin-Lowering Effect of Magnesium in Patients with Medullary Carcinoma of the Thyroid
}

\author{
Constantine Anast, Louis David, John Winnacker, Robert Glass, \\ William Baskin, Leonard Brubaker, and Thomas Burns \\ From the Division of Endocrinology, Departments of Child Health and \\ Medicine, School of Medicine, University of Missouri and Veterans \\ Administration Hospital, Columbia, Missouri 65201
}

\begin{abstract}
A в S T RACT The effect of magnesium chloride or magnesium sulfate infusion on circulating levels of immunoreactive calcitonin (iCT) was evaluated on nine occasions in three patients with metastatic medullary carcinoma of the thyroid. One patient was normocalcemic and had normal circulating levels of immunoreactive parathyroid hormone (iPTH), one patient was hypocalcemic and had surgical hypoparathyroidism, and one patient had mild to moderate hypercalcemia associated with bone metastases. The basal serum iPTH levels were undetectable in the latter two patients. In every instance magnesium administration produced a rapid and striking fall in circulating $\mathrm{iCT}$ and usually a detectable fall in serum calcium. During the hypermagnesemic state, serum iPTH fell from normal to undetectable in the patient with normal parathyroid function, while serum iPTH levels remained undetectable in the hypoparathyroid patient and in the patient with hypercalcemia associated with bone metastases. The results of these studies indicate that: (a) contrary to what has been reported in normal experimental animals, magnesium administration lowers circulating $\mathrm{iCT}$ in human subjects with thyroid medullary carcinoma and (b) the calcium-lowering effect produced by magnesium in patients with medullary carcinoma may, in part at least, be due to a redistribution of body calcium that is not mediated by the actions of either parathyroid hormone or calcitonin.
\end{abstract}

\section{INTRODUCTION}

It has been well established that the secretion of calcitonin is under the control of the blood calcium level

A preliminary report of this research was presented at the 48th Annual Meeting of the Central Society for Clinical Research, November 1974.

Received for publication 10 June 1975 and in revised form 18 August 1975. with hypercalcemia stimulating the release of this hormone from the thyroid gland. There are many similarities, both biological and chemical, between magnesium and calcium and the possibility that magnesium might influence calcitonin secretion has, therefore, been studied in experimental animals by several investigators. The reports of in vitro, in situ, and in vivo animal studies all indicate that magnesium, like calcium, stimulates the release of calcitonin from the thyroid gland (1-4). Moreover, on the basis of the results of the in vivo studies, it has been suggested that the characteristic hypocalcemic effect produced by magnesium administration is the result of magnesium-induced release of calcitonin.

In normal man, the serum concentration of calcitonin is low and, because of methodologic problems, difficult to quantify. Therefore, the secretion of calcitonin in human subjects has been most extensively studied in patients with medullary carcinoma of the thyroid, who characteristically have high circulating levels of the hormone. Similar to what has been observed in normal experimental animals, the administration of calcium increases the serum calcitonin concentration in these patients. However, there is little information concerning the possible interrelationship of magnesium and calcitonin in man. The purpose of the present investigation was to study the effect of magnesium administration on circulating levels of calcitonin in patients with medullary carcinoma of the thyroid. Much to our surprise and in direct contrast to the reported studies in normal laboratory animals, we found that experimentally-induced hypermagnesemia consistently produced a rapid and striking fall in the serum calcitonin concentration in these patients.

\section{METHODS}

\section{Laboratory methods}

Serum and urine calcium and magnesium were determined by atomic absorption spectrophotometry (model 303 
spectrophotometer, Perkin-Elmer Corp., Norwalk, Conn.) and inorganic phosphorus by the method of Fiske and Subbarow adapted to the Technicon Auto: Analyzer (Technicon Instruments Corp., Tarrytown, N. Y.) (5). Serum levels of immunoreactive parathyroid hormone $(\mathrm{iPTH})^{1}$ were determined by a double-antibody radioimmunoassay technique developed in our laboratory $(6)$. Human hyperparathyroid serum is used as a reference standard in the assay and the concentration of il'TH in unknown serum samples is expressed as microliter equivalents of standard hyperparathyroid serum per milliliter $(\mu \mathrm{leq} / \mathrm{ml})$; normal values range from undetectable to $10 \mu \mathrm{le} / \mathrm{ml}$.

Serum immunoreactive calcitonin (iCT) was measured by an immunoassay procedure developed in our laboratory. Synthetic human calcitonin $\mathrm{M}$ is labeled with ${ }^{131} \mathrm{I}$ at specific radioactivities of $250-500 \mu \mathrm{Ci} / \mu \mathrm{g}$ and purified by adsorbing to Quso G 32 (Philadelphia Quartz Co., Philadelphia, Pa.) followed by elution with a solution of $20 \%$ acetone- $1 \%$ acetic acid. The incubation buffer is Tris buffer $0.5 \mathrm{Ml}$ at $\mathrm{pH}$ 7.8. The final incubation mixture is $500 \mu \mathrm{l}$ and contains $100 \mu \mathrm{l}$ of either standard or unknown serum, antiserum at a final concentration of $1: 20,000,{ }^{131}$ I-labeled calcitonin, and buffer. The antiserum to human calcitonin was made by injecting rabbits with synthetic human calcitonin M. A nonequilibrium incubation system is used in which the unlabeled standard human calcitonin or unknown serum samples are preincubated at $4^{\circ} \mathrm{C}$ with antiserum for 3 days and then with labeled calcitonin for an additional 3-4 days. After incubation, free and bound calcitonin ${ }^{131} \mathrm{I}$ are separated by dextran-charcoal. The supernate and precipitate of each standard and unknown sample are counted in a gamma counter and a bound-to-free ratio is calculated.

It has been demonstrated that serum samples can produce nonspecific displacement of tracer from antibody in the calcitonin immunoassay procedure (7). Therefore, to eliminate or minimize this artifact, calcitonin concentration was determined in the serum samples before and after charcoal adsorption, according to the procedure described by Deftos (7). In the serum samples obtained in this study the calculated iCT concentrations were 2-18\% lower after the addition of charcoal. Quantitatively, the effect produced by the apparent interfering substances on the immunoassay determination of calcitonin was relatively constant in various serum samples obtained from any one patient.

With our immunoassay procedure the concentration of serum iCT in normal children and adults ranges from undetectable in most subjects $(<0.1 \mathrm{ng} / \mathrm{ml})$ to less than 0.2 $\mathrm{ng} / \mathrm{ml}$. The intraassay variation is less than $8 \%$ while the interassay variation is less than $15 \%$. Sequential serum samples obtained in each of the study periods to be described were always analyzed in the same assay, thus eliminating the effect of interassay variation.

Patient 1, a 64-yr-old $(60-\mathrm{kg})$ white male librarian, had a total thyroidectomy and radical neck dissection $3 \mathrm{yr}$ before the study. Histological studies revealed medullary carcinoma of the thyroid with cervical lymph node metastases. In addition, there was evidence of liver and pulmonary metastases. Postoperatively he developed hypocalcemia and the diagnosis of surgical hypoparathyroidism was made. The serum iCT concentration on admission was $11.6 \mathrm{ng} / \mathrm{ml}$. The serum calcium level was $7.0 \mathrm{mg} / 100 \mathrm{ml}$, serum magnesium $1.8 \mathrm{mg} / 100 \mathrm{ml}$, and serum phosphorus $5.9 \mathrm{mg} / 100$ $\mathrm{ml}$. The serum iPTH was undetectable.

${ }^{1}$ Abbreciations used in this paper: $\mathrm{iCT}$, immunoreactive calcitonin; iPTH, immunoreactive parathyroid hormone.
Paticnt 2, a 74-yr-old (44-kg) white housewiie, had a total thyroidectomy and radical neck dissection 18 mo before the study. Histological studies revealed medullary carcinoma of the thyroid with cervical lymph node metastases. There was evidence of liver metastases as well as metastatic bone disease as revealed by lytic lesions of the caliarium and $\mathrm{X}$-ray changes in the dorsal and limbar spine. The serum iCT level on admiss:on was $138 \mathrm{ng} / \mathrm{ml}$. The serum calcium level was $11.2 \mathrm{mg} / 100 \mathrm{ml}$, serum magnesium $1.8 \mathrm{mg} / 100 \mathrm{ml}$, and serum phosphorus $3.4 \mathrm{mg} / 100 \mathrm{ml}$. The serum iPTH was undetectable.

Paticnt 3, a 50-yr-old (65-kg) white housewife, had medullary carcinoma of the thyroid with cervical lymph node metastases. The leit lobe of the thyroid was removed $3 \mathrm{yr}$ and the right lobe 1 year before the study. On admission the serum iCT was $0.89 \mathrm{ng} / \mathrm{ml}$, serum calcium $9.50 \mathrm{mg} / 100 \mathrm{ml}$, serum magnesium $2.1 \mathrm{mg} / 100 \mathrm{ml}$, and serum phosphorus $3.8 \mathrm{mg} / 100 \mathrm{ml}$. The serum iPTH level was $9.0 \mu \mathrm{eq} / \mathrm{ml}$.

In summary, the three patients of this study were similar in that each had had a thyroidectomy followed by clinical evidence of metastases and persistence of elevated serum iCT levels. In each the serum sodium, potassium, bicarbonate. chloride, and blood urea nitrogen were within normal limits. The patients differed in the following respects: (a) patient 1 developed hypocalcemia with undetectable levels of serum iPTH after thyroid surgery and was considered to have surgical hypoparathyroidism; (b) patient 2 had hypercalcemia associated with the radiologic evidence of metastatic bone disease and undetectable levels of serum iPTH; and $(c)$ patient 3 was normocalcemic and base-line iPTH levels were within the normal range.

\section{Magnesium infusion procedure}

All subjects studied were hospitalized on the ward of the Clinical Research Center. The protocols followed were approved by the institution's Committee for Projects Involving Human Subjects. The study was explained to each subject and written consent obtained.

The patients received a regular diet and the infusion procedures were carried out aiter an overnight fast. Magnesium sulfate or magnesium chloride was administered intravenously in $5 \%$ dextrose water during time intervals that ranged from $\frac{1}{2}$ to $6 \mathrm{~h}$. The rate of infusion was adjusted in each study to achieve serum magnesium levels of approximately $4-6 \mathrm{mg} / 100 \mathrm{ml}$ as determined by frequent periodic magnesium determinations. During the infusion procedure a physician was in constant attendance and, in addition to frequent serum magnesium determinations, the patients were carefully evaluated by a cardiac monitor and by testing of deep tendon reflexes. Except for a mild flushing sensation, the patients experienced no side effects during the infusions.

\section{RESULTS}

Paticnt 1 (hypocalcomic-lyypoparathyroid). Fig. 1A shows the effect in patient 1 of the infusion of $520 \mathrm{mg}$ of magnesium as magnesium sulfate over a 2 -h period on serum magnesium, $\mathrm{iCT}$, calcium, phosphorus, and iPTH. As the serum magnesium increased there was a rapid fall in serum $\mathrm{iCT}$, and as the serum magnesium decreased after discontinuation of the infusion there was a rise in serum $\mathrm{iCT}$ toward base-line levels. There was little change in the serum calcium during magnesium 


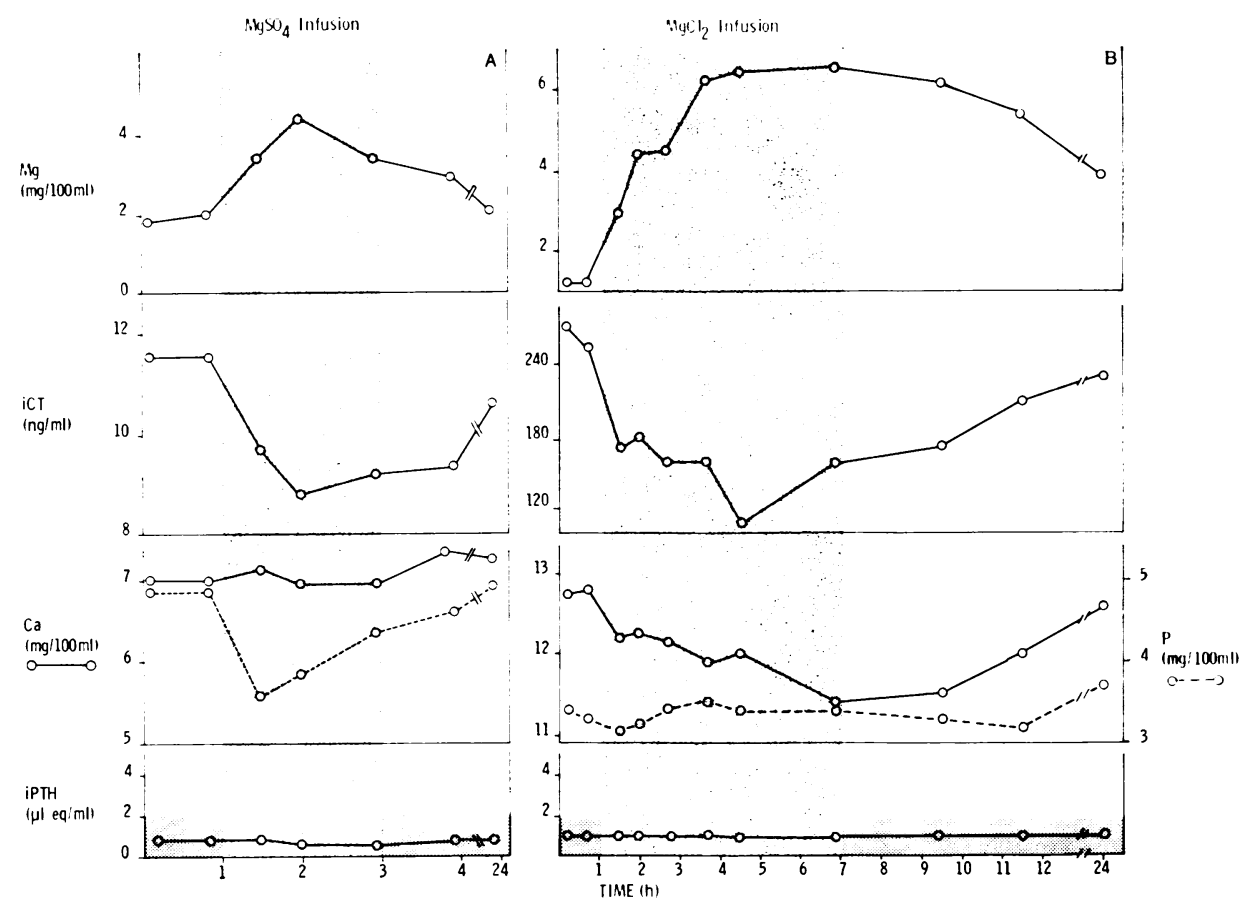

FIGURE 1 (A) The effect of the infusion of $520 \mathrm{mg}$ of magnesium as magnesium sulfate over a 2 -h period on serum magnesium, iCT, calcium, phosphorus, and iPTH in patient 1 . The shaded area in the lower panel in this and subsequent figures indicates limits of detectability of parathyroid hormone immunoassay. (B) The effect of the infusion of $2.250 \mathrm{mg}$ of magnesium as magnesium chloride over a 6 - $h$ period on serum magnesium, $\mathrm{iCT}$, calcium, phosphorus, and iPTH in patient 2.

infusion, although a modest increase was observed after the infusion was discontinued. A fall in serum phosphorus was observed during magnesium infusion, while the serum iPTH remained undetectable throughout the entire period of study.

Patient 2 (hypercalcemic-bone metastases). The effect of a relatively long-term infusion of magnesium in patient 2 is shown in Fig. 1B. 2,250 mg of magnesium as magnesium chloride was infused over a 6 -h period. The serum magnesium level increased to a high of 6.4 $\mathrm{mg} / 100 \mathrm{ml}$ during the infusion and then declined slowly to a level of $3.8 \mathrm{mg} / 100 \mathrm{ml}$ over the 17 -h period following the discontinuation of the infusion. The serum iCT declined rapidly during the infusion to a low point that was less than $50 \%$ of control values. As the serum magnesium concentration declined after the discontinuation of the infusion, the serum iCT slowly increased, but was still below base-line levels $17 \mathrm{~h}$ after the end of the infusion, when the serum magnesium concentration was $3.8 \mathrm{mg} / 100 \mathrm{ml}$. In general, the changes in serum calcium paralleled the changes in serum iCT. Thus, the initial fall in serum iCT was accompanied by a fall in serum calcium and the rise in serum iCT that occurred after the infusion was accompanied by a rise in serum calcium.
No distinct pattern in serum phosphorus was observed although there was a slight and transient decrease during the $1 \mathrm{st} \mathrm{h}$ of the magnesium infusion. The serum iPTH remained undetectable throughout the period of study.

Patient 3 (normocalcemic-normal dctectable serum $i P T H$ ). The effect of the infusion of $1.190 \mathrm{mg}$ of magnesium as magnesium chloride over a 3 -h period in patient 3 is seen in Fig. 2A. During the infusion period the serum iCT decreased rapidly and was accompanied by a fall in serum calcium, a rise in serum phosphorus, and a progressive decrease in serum iPTH to an undetectable level. Within an hour after the discontinuation of the infusion, when the serum magnesium was slowly returning toward baseline and the serum calcium was continuing to fall, the serum iPTH increased and subsequently reached base-line levels $2 \mathrm{~h}$ after discontinuation of the infusion.

The effect of the infusion of $480 \mathrm{mg}$ of magnesium as magnesium sulfate over a $\frac{1}{2}-h$ period in patient 3 is shown in Fig. 2B. The pattern of response was similar to that produced by magnesium chloride (Fig. 2A) except that the serum phosphorus decreased rather than increased. 


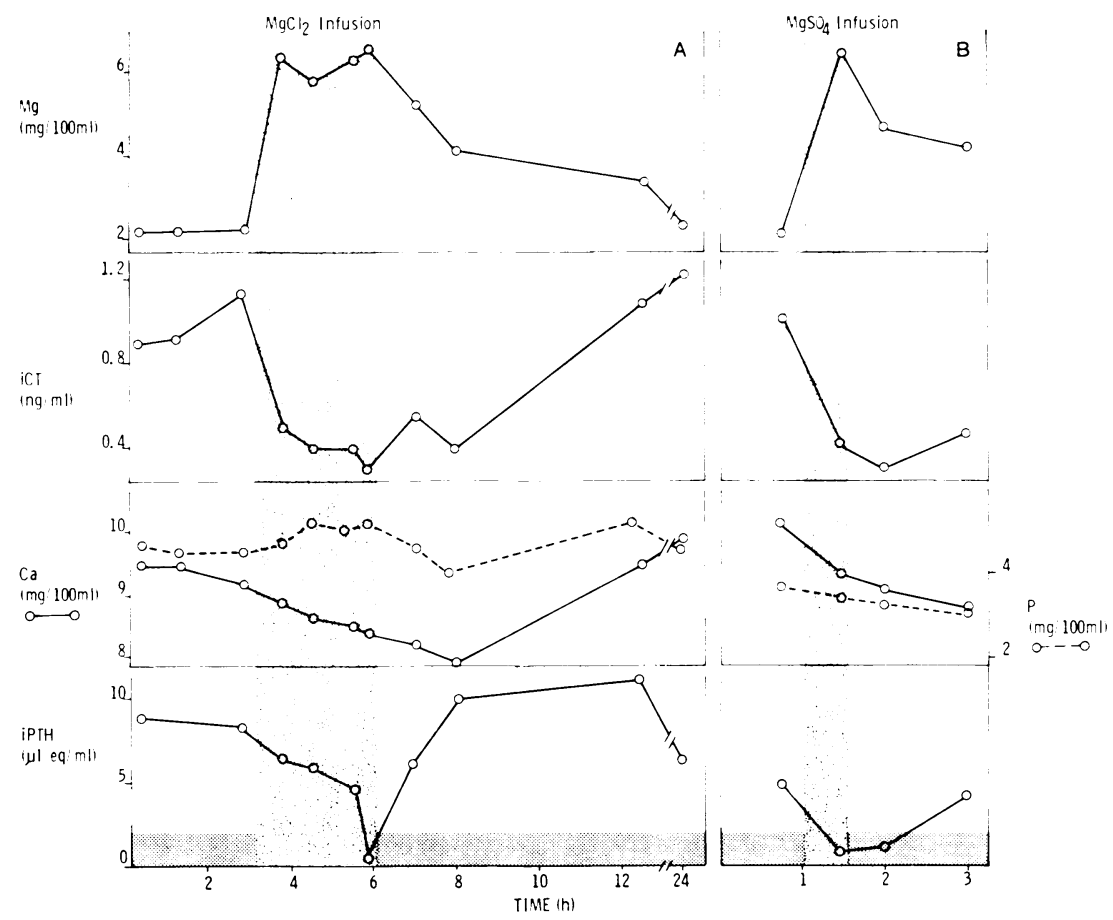

Figure 2 (A) The effect of the infusion of $1,190 \mathrm{mg}$ of magnesium as magnesium chloride over a 3-h period on serum magnesium, iCT, calcium, phosphorus, and iPTH in patient 3. (B) The effect of the infusion of $480 \mathrm{mg}$ of magnesium as magnesium sulfate over a $\frac{1}{2}-\mathrm{h}$ period on serum magnesium, iCT, calcium, phosphorus, and $\mathrm{iPTH}$ in patient 3 .

The possibility that magnesium might blunt the response of medullary carcinoma cells to calcium stimuli was considered. To investigate this possibility, the effect of intravenous calcium administration on the depression of serum calcitonin produced by a magnesium load was studied in patient 3 . The results are presented in Fig. 3. 1,400 $\mathrm{mg}$ of magnesium as magnesium chloride was infused over a $4 \frac{1}{2}-\mathrm{h}$ period. During the last $1 \frac{1}{4} \mathrm{~h}$ of the magnesium infusion $675 \mathrm{mg}$ of calcium as calcium gluconate was also infused. The magnesium infusion resulted in the usual fall in serum iCT, but when calcium infusion was superimposed on the magnesium infusion to produce a rise of $2 \mathrm{mg} / 100 \mathrm{ml}$ in serum calcium, there was almost a 10 -fold increase in the serum iCT concentration. It should be noted that in this study the depression of serum $\mathrm{iCT}$ produced by hypermagnesemia was not accompanied by a detectable change in serum calcium, though a distinct increase in serum phosphorus was observed.

As part of the study depicted in Fig. 2A, the effect of magnesium infusion on the urinary excretion of magnesium, calcium, and phosphorus in patient 3 was investigated. $1,190 \mathrm{mg}$ of magnesium as magnesium chloride was infused over a 3 - $\mathrm{h}$ period. In the 3 - $\mathrm{h}$ period following the infusion the urinary calcium and mag- nesium each increased by approximately $300 \%$, while urinary phosphorus decreased to $50 \%$ of base-line values obtained $3 \mathrm{~h}$ before the infusion.

Serum protein concentrations remained relatively constant during all of the infusion studies with no consistent pattern of change.

Additional magnesium infusion studies. The effect of magnesium infusion on circulating iCT was evaluated on three additional occasions in patient 2 and one additional occasion in patient 3 . The results are summarized in Table I, where basal values and maximum deviations from basal values induced by magnesium infusion are shown. In three of the four additional studies, magnesium administration produced a parallel fall in serum $\mathrm{iCT}$ and serum calcium. The only exception was study $2 a$ where a detectable fall in serum calcium followed the initial decrease in serum iCT.

\section{DISCUSSION}

The results of these studies indicate that the intravenous administration of magnesium chloride or magnesium sulfate leads to a fall in circulating iCT in patients with metastatic medullary carcinoma of the thyroid. This finding is in direct contrast to previously published reports which indicate that magnesium stimulates calcitonin re- 


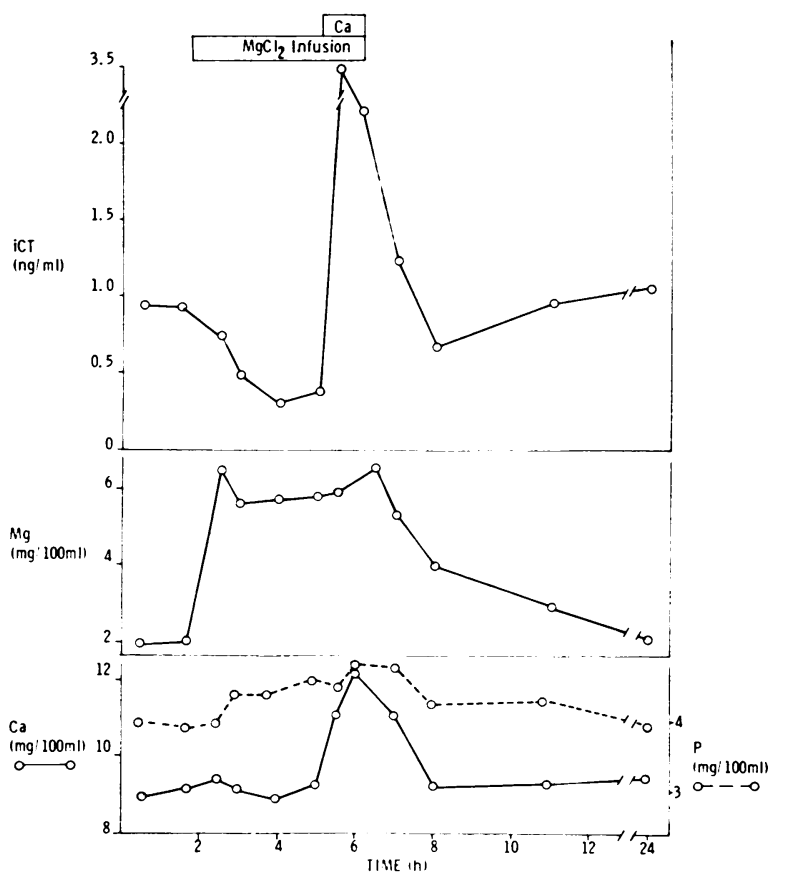

FIgURE 3 The effect of calcium administration on the serum calcitonin-lowering effect produced by magnesium infusion in patient $3.1,400 \mathrm{mg}$ of magnesium as magnesium chloride was infused over a $4 \frac{1}{2}$-h period. During the last $1 \frac{1}{4} \mathrm{~h}$ of the magnesium infusion $675 \mathrm{mg}$ of calcium as calcium gluconate was also infused.

lease in normal experimental animals (1-4). Bell (1) and Radde et al. (2) demonstrated that magnesium stimulated the release of calcitonin from porcine thyroid gland slices incubated in a Krebs-Ringer buffer. Care et al. (3) observed that magnesium perfusion stimulated the release of calcitonin from porcine thyroid glands isolated in situ. In in vivo studies in the pig, Littledike and Arnaud (4) found that the infusion of magnesium led to an increase in circulating iCT, which was accompanied by a fall in plasma calcium.

The reason for the disparity between our findings and the findings of in vitro, in situ, and in vivo studies in the normal pig is unknown. It is possible that the divergent responses are simply due to a species difference. However, it seems more likely that they reflect basic differences in metabolic or secretory characteristics of thyroid medullary carcinoma cells as compared to normal C cells.

Although it is clear that magnesium administration caused a fall in serum iCT in our patients, it is uncertain if this was due to a direct action of magnesium on the synthesis or release of calcitonin, or whether the calcitonin-lowering effect was mediated through a secondary mechanism such as a fall in circulating calcium. In seven of the nine infusion studies reported in this paper, magnesium administration led to a decline in serum calcium. In six of the seven studies the fall in serum calcium paralleled the fall in serum iCT, while in one study the fall in serum calcium followed the fall in serum iCT (study $2 a$ in Table I). It has been demonstrated that lowering of the serum calcium level by EDTA administration leads to a decline in circulating $\mathrm{iCT}$ in patients with medullary carcinoma of the thyroid (8). However, the minimal decrease in serum calcium required to reduce serum $\mathrm{iCT}$ in these patients has not been defined. It is possible that thyroid medullary carcinoma cells are extremely sensitive (more so than normal C cells) to small decrements in serum calcium which in some cases might go undetected with presently available methods.

Another possibility to account for our findings is that magnesium might in some way interfere with the response of medullary carcinoma cells to calcium. However, this did not appear to be the case; when calcium infusion was superimposed on magnesium infusion there was an almost 10 -fold increase in serum iCT concentration (Fig. 3). The calcium-induced increase in serum iCT was similar in magnitude to that reported by Melvin et al. (9) in a series of patients with overt medullary carcinoma of the thyroid. Nevertheless, the possibility that hypermagnesemia blunts the response of medullary carcinoma cells to physiologic levels of calcium, per-

TABLE I

Additional Magnesium Infusion Studies

\begin{tabular}{|c|c|c|c|c|c|c|c|c|c|c|c|c|c|}
\hline \multirow{3}{*}{$\begin{array}{l}\text { Patient } \\
\text { no. }\end{array}$} & \multicolumn{3}{|c|}{$\mathbf{M g}$ infusion } & \multirow{2}{*}{\multicolumn{2}{|c|}{ Serum $\mathbf{M g}$}} & \multirow{2}{*}{\multicolumn{2}{|c|}{ Serum iCT }} & \multirow{2}{*}{\multicolumn{2}{|c|}{ Serum $\mathrm{Ca}$}} & \multirow{2}{*}{\multicolumn{2}{|c|}{ Serum $\mathbf{P}$}} & \multirow{2}{*}{\multicolumn{2}{|c|}{ Serum iPTH }} \\
\hline & \multirow[b]{2}{*}{ Salt } & \multirow{2}{*}{$\begin{array}{c}\text { Dose } \\
\mathbf{M g}\end{array}$} & \multirow{2}{*}{$\begin{array}{c}\text { Dura- } \\
\text { tion }\end{array}$} & & & & & & & & & & \\
\hline & & & & Basal & $\operatorname{Max} \Delta^{*}$ & Basal & $\operatorname{Max} \Delta$ & Basal & $\operatorname{Max} \Delta$ & Basal & $\operatorname{Max} \Delta$ & Basal & $\operatorname{Max} \Delta$ \\
\hline & & $m g$ & $h$ & & $m l$ & & & & $m l$ & & $\mathrm{ml}$ & & $m l$ \\
\hline $2 a$ & $\mathrm{MgSO}_{4}$ & 480 & 1 & 1.8 & +4.4 & 140 & -44 & 11.2 & -0.8 & 3.7 & -0.8 & 0 & $c$ \\
\hline $2 b$ & $\mathrm{MgSO}_{4}$ & 620 & $1 \frac{1}{2}$ & 1.8 & +3.5 & 151 & -43 & 11.3 & -0.6 & 3.7 & -0.8 & 0 & 0 \\
\hline $2 c$ & MgSO, & 700 & 2 & 1.6 & +4.6 & 144 & -47 & 11.2 & -0.4 & 3.8 & -0.7 & 0 & 0 \\
\hline 3 & $\mathrm{MgCl}_{2}$ & 1,400 & 4 & 2.0 & +4.1 & 0.87 & -0.61 & 9.3 & -1.4 & 3.7 & +0.4 & 6.5 & -6.5 \\
\hline
\end{tabular}

* Maximum deviation induced by magnesium infusion. 
haps by competing for binding sites, has not been definitely ruled out.

Littledike and Arnaud (4) observed that the response of intact pigs to magnesium chloride infusion was characterized by a rise in serum iCT and a fall in serum calcium, while magnesium infusion in a thyroparathyroidectomized pig led to a rise in serum calcium with no detectable change in serum iCT. On the basis of these findings, the investigators suggested that the major factor responsible for the hypocalcemic effect of magnesium is calcitonin. This possibility is consistent with previous reports which indicate that magnesium administration lowers the serum calcium level in intact, but not thyroidectomized, cats and rats $(10,11)$. In our studies of patients with medullary carcinoma the fall in serum calcium produced by the administration of magnesium chloride or magnesium sulfate (observed in seven of nine studies) was accompanied by a fall, rather than a rise, in serum iCT. Therefore, the calcium-lowering effect produced by magnesium in these patients cannot be attributed to a calcitonin effect as was postulated in animal studies.

The fall in serum iPTH produced by magnesium administration in patient 3 is consistent with previously published observations that magnesium inhibits parathyroid hormone secretion $(12,13)$, except in certain patients with magnesium deficiency where magnesium may actually stimulate the release of parathyroid hormone $(14,15)$. The fall in serum calcium (Fig. 2) and in urine phosphorus in patient 3 could be secondary to the fall in serum iPTH produced by magnesium. However, in patient 2 with hypercalcemia and bone metastases, a fall in serum calcium was observed in the presence of a consistently undetectable serum iPTH level. Thus, in this patient the calcium-lowering effect produced by magnesium cannot be attributed to either a rise in circulating $\mathrm{iCT}$ or a detectable fall in circulating iPTH. This observation suggests that the calciumlowering effect produced by magnesium is, in part at least, due to a redistribution of body calcium that is not mediated through the actions of either parathyroid hormone or calcitonin.

The hypocalcemic effect produced by magnesium infusion could be related to the calciuric effect of magnesium $(16,17)$, which has been attributed to competitive inhibition of tubular calcium reabsorption. We observed a calciuric effect secondary to magnesium infusion in patient 3 , while urinary excretion studies were not carried out in the other two patients.

The changes in serum phosphorus levels induced by magnesium infusion in our patients are of interest. In some of our studies the administration of magnesium resulted in a fall in serum phosphorus while in other studies there was either no change or a modest increase in serum phosphorus. Analysis of our data indicates that the response of serum phosphorus appeared to be related to the anion that was infused with magnesium, with the lowering of the serum phosphorus being associated with sulfate infusion. A hypophosphatemic effect of sodium sulfate has been previously noted and in one study was associated with a modest increase in urinary phosphate excretion $(18,19)$.

Recently Gautvik and Tashjian (20) reported studies of calcitonin release in a human medullary carcinoma maintained in tissue culture. In this in vitro study magnesium alone or in combination with calcium did not influence the release of calcitonin. However, an unphysiologically high calcium concentration (20 $\mathrm{mM}$ ) was necessary to stimulate calcitonin release in culture while low calcium concentrations $(0.5 \mathrm{mM})$ did not affect hormone release. The significance of this single in vitro study relative to in vivo studies in patients with medullary thyroid carcinoma is uncertain.

Although the mechanism has not been elucidated, it is clear that magnesium lowers circulating $\mathrm{iCT}$ in patients with medullary carcinoma of the thyroid. Although we have attributed this finding to a direct or indirect effect of magnesium on the release and/or synthesis of calcitonin, it is possible that magnesium in some way alters the degradation of calcitonin in patients with medullary thyroid carcinoma. Further studies are needed to clarify this possibility.

Lnder basal conditions patient 1 had loose stools approximately every half hour and marked borborygmi. It is of interest that for several hours during and after magnesium infusion there was distinct abatement in these symptoms. It is possible that this improvement was related to the fall in circulating calcitonin since it has been suggested that the diarrhea occurring in association with medullary carcinoma of the thyroid may be due to calcitonin inhibition of sodium and water absorption by the intestine (21). On the other hand, high contents of serotonin and prostaglandins have been found in some thyroid medullary carcinomas and both of these compounds are known to stimulate smooth muscle (2224). The possibility that, in addition to its effect on calcitonin, magnesium might influence the secretion or synthesis of other bioactive substances produced by thyroid medullary carcinomas, including prostaglandins, serotonin, $\mathrm{ACTH}$, and histaminase, is currently under investigation.

\section{ACKNOWLEDGMENTS}

We wish to express gratitude for the expert technical assistance of Mrs. Marcia Schweiss, Mrs. Sammy Langeluttig, and Dr. Arsenia Rodrigues and also for the excellent secretarial assistance of Mrs. Fern McClanahan in the preparation of this manuscript.

This research was supported in part by Public Health Service Research Grants HD-02756 and FR-00287. 


\section{REFERENCES}

1. Bell, N. H. 1970. Effects of glucagon, dibutyryl cyclic $3^{\prime}, 5^{\prime}$-adenosine monophosphate, and theophylline on calcitonin secretion in vitro. J. Clin. Invest. 49: 1368-1373.

2. Radde, I. C., D. K. Parkinson, E. R. Witterman, and B. Höffken. 1969. Magnesium and calcium as stimuli to in vitro release of calcitonin from thyroid slices. In Calcitonin 1969, Proceedings of the Second International Symposium. S. Taylor and G. Foster, editors. William Heinemann (Medical Books), Ltd., London. 376-380.

3. Care, A. D., N. H. Bell, and R. F. L. Bates. 1971. The effect of hypermagnesaemia on calcitonin secretion in vivo. J. Endocrinol. 51:381-386.

4. Littledike, E. T., and C. D. Arnaud. 1971. The influence of plasma magnesium concentrations on calcitonin secretion in the pig. Proc. Soc. Exp. Med. Biol. 136: 10001006.

5. Fiske, C. H., and Y. Subbarow. 1926. The colorimetric determination of phosphorus. J. Biol. Chem. 66: 375400.

6. Conaway, H. H., and C. S. Anast. 1974. Double-antibody radioimmunoassay for parathyroid hormone. $J$. Lab. Clin. Med. 83: 129-138.

7. Deftos, L. J. 1971. Immunoassay for human calcitonin. I. Method. Metab. Clin. Exp. 20: 1122-1128.

8. Deftos, L. J., A. D. Goodman, K. Engelman, and J. T. Potts, Jr. 1971. Suppression and stimulation of calcitonin secretion in medullary thyroid carcinoma. Metab. Clin. Exp. 20: 428-431.

9. Melvin, K. E. W., A. H. Tashjian, Jr., and H. H. Miller. 1972. Studies in familial (medullary) thyroid carcinoma. Recent Prog. Horm. Res. 28: 399-470.

10. Radde, I. C., E. R. Witterman, and S. Pensuwan. 1968. Effect of thyroid and parathyroid on hypocalcemia occurring after a magnesium load. Endocrinology. 83: 1285-1292.

11. Nielsen, S. P. 1970. Abolition of magnesium-induced hypocalcaemia by acute thyro-parathyroidectomy in the cat. Acta Endocrinol. 64: 150-158.

12. Buckle, R. M., A. D. Care, C. W. Cooper, and H. J. Gitelman. 1968. The influence of plasma magnesium concentration on parathyroid hormone secretion. J. Endocrinol. 42 : $529-534$.
13. Pletka, P., D. S. Bernstein, C. L. Hampers, J. P. Merrill, and L. M. Sherwood. 1971. Effects of magnesium on parathyroid hormone secretion during chronic haemodialysis. Lancet. 2 : 462-463.

14. Anast, C. S., J. M. Mohs, S. L. Kaplan, and T. W. Burns. 1972. Evidence for parathyroid failure in magnesium deficiency. Scicnce (Wash. D. C.). 177: 606608.

15. Suh, S. M., A. H. Tashjian, Jr., N. Matsuo, D. K. Parkinson, and D. Fraser. 1973. Pathogenesis of hypocalcemia in primary hypomagnesemia: normal endorgan responsiveness to parathyroid hormone, impaired parathyroid gland function. J. Clin. Inc'est. 52: 153-160.

16. Mendel, L. B., and S. R. Benedict. 1909. The paths of excretion for inorganic compounds. IV. The excretion of magnesium. Am. J. Physiol. 25 : 1-22.

17. Jones, K. H.. and P. Fourman. 1966. Effects of infusions of magnesium and of calcium in parathyroid insufficiency. Clin. Sci. (Oxf.). 30: 139-150.

18. Chakmakjian, Z. H., and J. E. Bethune. 1966. Sodium sulfate treatment of hypercalcemia. N. Engl. J. Med. 275 : 862-869.

19. Fulmer, D. H., A. B. Dimich, E. O. Rothchild, and W. P. L. Myers. 1972. Treatment of hypercalcemia. Comparison of intravenously administered phosphate, sulfate, and hydrocortisone. Arch. Intern. Med. 129: 923-930.

20. Gautvik, K. M., and A. H. Tashjian, Jr. 1974. Human medullary thyroid carcinoma: control of calcitonin secretion in viro and in tissue culture. Horm. Metab. Res. 6: 70-73.

21. Gray, T. K., F. A. Bieberdorf, and J. S. Fordtran. 1973. Thyrocalcitonin and the jejunal absorption of calcium, water, and electrolytes in normal subjects. J. Clin. Invest. 52 : 3084-3088.

22. Cope, C. S., and E. D. Williams. 1967. Clinicopathological conference: a case of diarrhea and goiter. $\mathrm{Br}$. Med. J. $3:$ 293-297.

23. Ibanez, M. L., V. W. Cole, W. O. Russel, and R. L. Clark. 1967. Solid carcinoma of the thyroid Analyses of 53 cases. Cancer. $20:$ 706-723.

24. Williams, E. D., S. M. M. Karim, and M. Sandler. 1968. Prostaglandin secretion by medullary carcinoma of the thyroid. A possible case of associated diarrhoea. Lancet. 1: 22-23. 